\title{
Impact of Budget Deficit on Private Consumption inWAEMU Countries: Evidence from Pooled Mean Group Estimation
}

\author{
Yaya Keho ${ }^{1}$ \\ ${ }^{1}$ Ecole Nationale Supérieure de Statistique et d'Economie Appliquée (ENSEA) Abidjan, Abidjan, Côte d'Ivoire \\ Correspondence: Yaya Keho, Ecole Nationale Supérieure de Statistique et d'Economie Appliquée (ENSEA) \\ Abidjan, 08 BP 03 Abidjan 08, Côte d'Ivoire. Tel: 225-2244-4124. E-mail: yayakeho@ yahoo.fr
}

Received: November 19, 2015

Accepted: January 11, 2016

Online Published: February 20, 2016

doi:10.5539/ijef.v8n3p189

URL: http://dx.doi.org/10.5539/ijef.v8n3p189

\begin{abstract}
This study empirically investigates the impact of budget deficit on private consumption in seven member countries of the West African Economic and Monetary Union (WAEMU), namely Benin, Burkina Faso, Côte d'Ivoire, Mali, Niger, Senegal and Togo. It applies the pooled mean group estimation method to annual data covering the period 1970 to 2013. The results show that budget deficit and per capita GDP have long run positive effects on household consumption whereas inflation rate is detrimental to private consumption. This suggests that private consumption cannot be held responsible for any crowding-out effects that budget deficit might have on long run aggregate demand and economic growth in WAEMU countries. Therefore, restricting the size of budget deficits is costly for the development of WAEMU countries.
\end{abstract}

Keywords: budget deficits, private consumption, pooled mean group estimation, WAEMU

\section{Introduction}

The effect of fiscal deficit on private consumption is a contentious issue in macroeconomic literature. The theoretical perspectives can be discussed under three major schools of thought. In this regard, the Keynesian theory holds that budget deficits have, by the working of the multiplier, a positive effect on private consumption. The Neoclassicals state that an increase in government expenditure crowds out private spending due to rise in interest rate while the Ricardian equivalence approach support that budget deficits are neutral to private consumption. Today, the general belief is that budget deficit is bad for the economy. This belief has made the reduction of size of budget deficits one of the cornerstones of short-term stabilization and medium-term adjustment programs in developing countries.

On the empirical front, many studies have examined the nexus between budget deficit and private consumption in order to test the validity of the theoretical views. However, these studies yielded mixed results across countries, data and methodologies. Most of these studies use standard panel data regression methods imposing cross-sectional homogeneity on all slope coefficients except the intercepts. As suggested by Pesaran and Smith (1995), under slope heterogeneity, these estimates are affected by a potentially serious heterogeneity bias, especially in small country samples. Furthermore, Sub-Saharan African countries have received little attention in the empirical literature.

The aim of this paper is to discover the effect of budget deficit on private consumption for the member countries of the West African Economic and Monetary Union (WAEMU). Faced with the vicious circle of persistent budget deficits, WAEMU member countries have adopted convergence criteria aiming at explicit targets for public debt and deficits to monitor their fiscal situation and achieve sustainable growth. Assessing the impact of budget deficit on private consumption not only helps understanding the impact of government spending on poverty reduction, but also sets a framework for discussion of fiscal policies. If budget deficit affects household consumption negatively, then the deficit target within WAEMU is absolutely relevant. On the contrary, if deficit has positive effect on household consumption, then restricting the size of public deficits becomes costly for development. Despite the significant implications of the issue for monetary unions the relationship between budget deficit and private consumption has not been explored for WAEMU countries. This study attempts to fill the gap. It uses the pooled mean group estimator proposed by Pesaran et al. (1999). Contrary to standard panel data methods, this estimator allows for slope heterogeneity in the short run while imposing restrictions only in the long run. 
The remainder of the paper is organized as follows. Section 2 presents a brief review of literature regarding the effects of budget deficit on private consumption. Section 3 contains a description of the data, the model and the methodology. Section 4 presents and analyses the empirical results. Finally, Section 5 provides summary and concluding remarks.

\section{Literature Review}

The debate on the effect of budget deficit on private consumption has stimulated a burgeoning literature in macroeconomics. There are three competing views regarding the effect of budget deficit on private consumption (Bernheim, 1989; Shaw, 1987; Barro, 1989). The Keynesian view argues that an increase in the budget deficit increases disposable income and stimulates private consumption (Keynes, 1936). The Neoclassicals state that an increase in government spending crowds out private consumption. The Neoclassical theory supports the Keynesian proposition but only in short run. In long run Neoclassicals assume full employment of resources, implying that output will not be affected by any change in the budget deficit. Increase in government spending will reduce private spending due to rise in interest rate. Full Ricardian equivalence entails that an increase in budget deficits, regardless the way of financing, should have no impact on output and private consumption. This holds because households internalize government's budget constraint into their own lifetime budget constraints (Kormendi, 1983; Modigliani \& Sterling, 1986; Cardia, 1997). Thus, any tax-induced change in public deficit will be exactly offset by a change in private savings and the level of aggregate demand will be unchanged. A modified or extreme version of Ricardian equivalence entails that an increase in budget deficits should have a negative impact on interest rates, output and private consumption (Wheeler, 1999). The basic assumption of Ricardian equivalence is that consumers are not liquidity or credit constrained. This assumption might not hold for developing economies where there are imperfections in the capital markets.

A growing body of research has tested the validity of these theories. The results from these empirical studies are however mixed and controversial across countries, data and methodologies. Most of these studies cover developed countries and other contexts different from Sub-Saharan Africa. For instance, Haque and Montiel (1989) rejected the Ricardian equivalence in fifteen countries out of sixteen developing countries. The basis of the rejection was the prevalence of liquidity constraint in those countries. Haque (1988) and Gupta (1992) have found empirical support for the Ricardian equivalence behavior for developing countries. Rock et al. (1989) examined the deficit-private consumption nexus for Trinidad, Barbados and Tobago, and found evidence supporting the Ricardian equivalence only for Barbados. The authors concluded that the validity of the Ricardian equivalence is an empirical issue and that the irrelevance of the government's debt-tax choice should be reconsidered and not ignored. Karras (1994) examined the change of private consumption in response to increases in government spending for a large sample of countries. He found that government spending and private consumption are better described as complementary rather than as substitutes. Ghatak and Ghatak (1996) found no support for the Ricardian equivalence for India. There are significant crowding out effects on private consumption. Khalid (1996) found support for the Ricardian equivalence for 12 out of the 17 developing countries studied. The presence of liquidity constraints explains the rejection of the Ricardian equivalence. He also reported that increases in public spending may have some expansionary effect on aggregate demand. In the case of Greece, Drakos (2001) explored the long-run relationship between government borrowing and private savings. His results indicated that as the budget deficit increased, household perceived the government bonds as net wealth; hence they increased their consumption, without considering the uncertainty of the future tax level. Ho (2001) supported the crowing out effect for a sample of 24 OECD countries. Giorgioni and Holden (2003) examined the validity of the Ricardian equivalence for ten developing countries (Burundi, El Salvador, Ethiopia, Honduras, India, Morocco, Nigeria, Pakistan, Sri Lanka and Zimbabwe). Their results indicated that for these countries the Ricardian equivalence held since there was a negative relationship between consumption and budget deficits, although not always significant. Nieh and Ho (2006) showed that private consumption and government spending in 23 OECD countries are complementary to each other. But, Berben and Brosens (2007) showed that an increase in government spending leads to a decline in private consumption in OECD countries. Tagkalakis (2008) used data on 10 OECD countries and found that to stimulate private consumption, fiscal policy is much better in recession. Schclarek (2007) studied the effects of fiscal policy on private consumption for a sample of 40 countries including 19 industrialized and 21 developing countries. The results indicated that government spending have Keynesian effects for both industrial and developing countries. Afzal (2012) found evidence supporting the Ricardian equivalence hypothesis for Pakistan. More recently Khan et al. (2015) analyzed the impact of government spending on private consumption in China and found that the two variables are positively related. 


\section{Methodology and Data}

\subsection{Model Specification}

The model used in this paper is built upon the following function:

$$
C_{i t}=\theta_{0}+\theta_{1} B_{i t}+\theta_{2} Y_{i t}+\theta_{3} F_{i t}+\theta_{4} \pi_{i t}+\mu_{i t}
$$

where $\mathrm{C}$ is real private consumption per capita, $\mathrm{B}$ is budget balance (surplus or deficit) as share of GDP, $\mathrm{Y}$ is real GDP per capita, $\mathrm{F}$ is financial development indicator and $\pi$ is inflation rate. Financial development is measured by domestic credit to private sector as share of GDP. This indicator is used as a proxy for liquidity constraints. It is expected that economic growth and financial development benefit private agents by giving them better access to goods and services and enhancing their well-being. Expectedly, the relationship between these two explanatory variables and private consumption is positive. That of budget deficit has no a priori sign from a theoretical point of view. The impact of inflation is negative because it lowers the real value of assets and incomes.

\subsection{The Pooled Mean Group Estimation}

The estimation technique makes used of the Pooled Mean Group (PMG) estimator proposed by Pesaran et al. (1999). Following Pesaran et al. (1999), Eq.(1) is viewed as the reduced form of an autoregressive distributive lag (ARDL) dynamic panel model.

$$
y_{i t}=\sum_{j=1}^{m} \lambda_{i j} y_{i t-j}+\sum_{j=0}^{n} \delta_{i j}^{\prime} x_{i t-j}+\mu_{i}+\varepsilon_{i t}
$$

Where $y_{i t}=C_{i t}, x_{i t}=\left(B_{i t}, Y_{i t}, F_{i t}, \pi_{i t}\right)$ is a $4 \times 1$ vector of explanatory variables; $\delta_{i j}$ are the $4 \times 1$ coefficient vectors; $\lambda_{i j}$ are scalars; and $\mu_{i}$ represents the country-specific effect. From this model, we derive the long-run relation as follows:

$$
y_{i t}=\theta_{i}^{\prime} x_{i t}+\mu_{i t}
$$

If the variables are cointegrated, then the error term $\mu_{i t}$ is an $\mathrm{I}(0)$ process for all $i$, and Eq.(2) can be reparameterized in the form of an unrestricted error correction model in which the short-run dynamics of the variables are influenced by the deviation from the long-run relationship:

$$
\Delta y_{i t}=\phi_{i}\left(y_{i t-1}-\theta_{i}^{\prime} x_{i t}\right)+\sum_{j=1}^{m-1} \lambda_{i j}^{*} \Delta y_{i t-j}+\sum_{j=0}^{n-1} \delta_{i j}^{* \prime} \Delta x_{i t-j}+\mu_{i}+\varepsilon_{i t}
$$

The error-correction speed of adjustment parameter, $\phi_{i}$ and the long-run coefficients, $\theta_{i}$, are of primary interest. One would expect $\phi_{i}$ to be significantly negative under the prior assumption that the variables exhibit a return to long-run equilibrium. The main interest of ARDL models is that the long run relationship and the short run parameters are estimated jointly. They also allow to deal with variables that are possibly of different order of integration, namely $\mathrm{I}(0)$ and $\mathrm{I}(1)$, and not simply I(1). This property is extremely useful given the low power of panel unit root tests in short samples.

The PMG estimator allows the short-run coefficients and the speeds of adjustment to vary freely across countries, but imposes common long-run coefficients. Thus, in this study the PMG estimator is based on the following error-correction model:

$$
\Delta C_{i t}=\theta_{0}+\phi_{i} S_{i t-1}+\sum_{j=1}^{p} \gamma_{1 i j} \Delta C_{i t-i}+\sum_{j=0}^{p} \gamma_{2 i j} \Delta B_{i t-i}+\sum_{j=0}^{p} \gamma_{3 i j} \Delta Y_{i t-i}+\sum_{j=0}^{p} \gamma_{4 i j} \Delta F_{i t-i}+\sum_{j=0}^{p} \gamma_{5 i j} \Delta \pi_{i t-i}+\mu_{i t}
$$

where $S_{i t-1}=\left(C_{i t-1}-\theta_{1} B_{i t}-\theta_{2} Y_{i t}-\theta_{3} F_{i t}-\theta_{4} \pi_{i t}\right)$

The Mean Group (MG) estimator proposed by Pesaran and Smith (1995) allows both short-and long-run parameters heterogeneity. It derives the long-run parameters for the panel as the unweighted average of the 
long-run estimates from the $\mathrm{N}$ individual country regressions. The long-run slope homogeneity hypothesis is tested via a Hausman test, where under the null hypothesis, the difference in the estimated coefficients between the MG and PMG are not significantly different and PMG estimators are consistent and more efficient than Mean Group (MG) estimators (Pesaran et al., 1999).

\subsection{Data}

The empirical investigation uses annual time series data for seven member countries of the West African Economic and Monetary Union (WAEMU) namely: Benin, Burkina Faso, Côte d'Ivoire, Mali, Niger, Senegal and Togo. Data on real private consumption per capita, real GDP per capita and credit to private sector as share of GDP were sourced from the World Development Indicators by the Word Bank. Data on budget deficit and inflation rate were obtained from the website of the Central Bank of West African States. Budget balance was taken as share of GDP. All data cover the time period of 1970-2013, except inflation rate which spans from 1972 to 2013. Private consumption and real GDP are used in their natural logarithms.

The descriptive statistics of all variables is described in Table 1. The matrix of Pearson correlation coefficients is summarized in Table 2. The figures show that correlations among explanatory variables are moderate and weak. Among explanatory variables, the pair of private credit (F) and real GDP (Y) has the biggest correlation coefficient (0.61) but this is less than 0.8 . Therefore, the study decides to use all variables in the empirical model.

Table 1. Descriptive statistics

\begin{tabular}{lccccc}
\hline Variable & Obs. & Mean & Std. Dev. & Min & Max \\
\hline Private consumption per capita (C) & 308 & 413.22 & 195.79 & 168.03 & 1023.72 \\
Budget balance (B) & 308 & -3.12 & 3.93 & -16.64 & 31.31 \\
Real GDP per capita $(Y)$ & 308 & 553.44 & 326.24 & 213.17 & 1836.61 \\
Credit to private sector (F) & 308 & 18.62 & 8.34 & 3.302 & 41.87 \\
Inflation $(\pi)$ & 297 & 5.49 & 7.89 & -14.21 & 57.71 \\
\hline
\end{tabular}

Table 2. Matrix of Pearson correlation coefficients

\begin{tabular}{llllll}
\hline & $\mathrm{C}$ & $\mathrm{B}$ & $\mathrm{Y}$ & $\mathrm{F}$ & $\pi$ \\
\hline $\mathrm{C}$ & 1.00 & & & & \\
$\mathrm{~B}$ & $-0.14^{*}$ & 1.00 & & & \\
$\mathrm{Y}$ & $0.96^{*}$ & $-0.15^{*}$ & 1.00 & & \\
$\mathrm{~F}$ & $0.61^{*}$ & $-0.36^{*}$ & $0.61^{*}$ & 1.00 & \\
$\pi$ & 0.04 & -0.01 & 0.09 & 0.05 & 1.00 \\
\hline
\end{tabular}

Note: $*$ denotes statistically significant at $5 \%$.

\section{Empirical Results}

The empirical analysis proceeds as follows. First, unit root tests are performed to assess whether the variables we use in the analysis are stationary. Second, long-run coefficients are estimated using the pooled mean group estimator. We test for the order of integration of the series using Levin, Lin and Chu pool (LLC, 2002), Im, Peseran and Shin (IPS, 2003) and Maddala and Wu (1999) Fisher-ADF unit root tests. The results reported in Table 3 indicate that variables budget deficit and inflation are significantly stationary at levels, whereas all other variables are stationary in first difference. 
Table 3. Results of panel unit root tests

\begin{tabular}{|c|c|c|c|c|c|c|}
\hline \multirow[b]{2}{*}{ Variables } & \multicolumn{2}{|c|}{ Level } & \multirow[b]{2}{*}{ ADF Fisher } & \multicolumn{3}{|c|}{ First difference } \\
\hline & IPS & LLC & & IPS & LLC & ADF Fishe \\
\hline \multirow[t]{2}{*}{$\mathrm{C}$ : Consumption } & -1.114 & -0.743 & 20.326 & $-17.072^{*}$ & $-17.498^{*}$ & $207.642^{*}$ \\
\hline & $(0.132)$ & $(0.228)$ & $(0.120)$ & $(0.000)$ & $(0.000)$ & $(0.000)$ \\
\hline \multirow{2}{*}{ Y : GDP } & 1.046 & 0.679 & 7.845 & -15.322 & -14.007 & 187.996 \\
\hline & $(0.852)$ & $(0.751)$ & $(0.897)$ & $(0.000)$ & $(0.000)$ & $(0.000)$ \\
\hline \multirow{2}{*}{ B: Budget } & -5.700 & -6.520 & 58.630 & -19.137 & -20.763 & 233.223 \\
\hline & $(0.000)$ & $(0.000)$ & $(0.000)$ & $(0.000)$ & $(0.000)$ & $(0.000)$ \\
\hline \multirow[t]{2}{*}{ F: Finance } & 0.543 & 0.225 & 10.673 & -9.165 & -9.613 & 107.106 \\
\hline & $(0.706)$ & $(0.589)$ & $(0.711)$ & $(0.000)$ & $(0.000)$ & $(0.000)$ \\
\hline \multirow[t]{2}{*}{$\pi$ : Inflation } & -10.187 & -12.439 & 107.974 & -21.000 & -22.327 & 252.663 \\
\hline & $(0.000)$ & $(0.000)$ & $(0.000)$ & $(0.000)$ & $(0.000)$ & $(0.000)$ \\
\hline
\end{tabular}

Note. IPS, LLC and ADF-Fisher are the Im, Pesaran and Shin (2003), Levin, Lin and Chu (2002) and Maddala and Wu (1999) Fisher-ADF panel unit root test. Values in parentheses are $p$-value. * (**) signifies rejection of the unit root hypothesis at the $5 \%(10 \%)$ level.

The estimation results from the Pooled Mean Group (PMG) and the Mean Group (MG) estimators are presented in Table 4. Both the individual and joint Hausman tests suggest strongly that the assumption of common long-run coefficients across countries cannot be rejected indicating that the PMG estimates are the appropriate ones. Not surprisingly, the MG regression identifies long-run coefficients less precisely and coefficients are mostly insignificant. We therefore focus our analysis only on the results obtained with the PMG estimator.

The estimates of the long-run parameters reveal a negative and significant impact of budget balance on private consumption. This suggests that budget deficit caused by public spending increases household consumption in WAEMU countries. Therefore, fiscal policies that promote budget surplus would have adverse effects on household consumption. This finding supports the Keynesian view of public spending. On the other hand, financial development measured as credit to private sector has no significant effects on private consumption, suggesting that access to credit does not contribute to increase household consumption in WAEMU member countries. The results also show that inflation has detrimental effect on household consumption.

The results also indicate that GDP per capita has a significant positive effect on private consumption in WAEMU countries. This implies that economic growth has been effective in increasing the average level of private consumption. Given this result, why has the economic growth failed to reduce poverty in WAEMU member countries? The findings of this study lend support to the widely-held view that economic growth is a necessary but not a sufficient condition for achieving poverty reduction. The extent of the social impact of economic growth depends on the growth rate itself and also on the level of income inequality. High income inequality undermines the benefit of growth for the poor. The estimates of the short-run parameters indicate that only GDP per capita has a positive effect on private consumption.

Table 4. Mean group and pooled mean group estimates

\begin{tabular}{|c|c|c|c|c|c|c|c|c|}
\hline \multirow[b]{2}{*}{ Variables } & \multicolumn{3}{|c|}{ PMG } & \multicolumn{3}{|c|}{ MG } & \multicolumn{2}{|c|}{ Test Hausman } \\
\hline & Coef. & S.E. & z-ratio & Coef. & S.E. & z-ratio & $h$ & $p$-value \\
\hline Budget & $-0.007^{*}$ & 0.002 & -2.63 & -0.003 & 0.004 & -0.84 & 0.798 & 0.371 \\
\hline GDP & $0.596^{*}$ & 0.082 & 7.19 & $0.854^{*}$ & 0.292 & 2.92 & 0.641 & 0.423 \\
\hline Finance & -0.001 & 0.001 & -0.69 & 0.001 & 0.003 & 0.09 & 0.181 & 0.670 \\
\hline Inflation & $-0.003^{*}$ & 0.001 & -2.28 & -0.002 & 0.001 & -1.28 & 0.894 & 0.344 \\
\hline \multicolumn{9}{|c|}{ Error correction term } \\
\hline \multirow[t]{2}{*}{$p h i$} & $-0.222^{*}$ & 0.070 & -3.16 & $-0.368^{*}$ & 0.059 & -6.20 & & \\
\hline & \multicolumn{6}{|c|}{ Test joint d'Hausman } & 0.63 & 0.959 \\
\hline$\Delta$ Budget & 0.001 & 0.001 & 0.99 & 0.001 & 0.001 & 1.37 & & \\
\hline$\Delta \mathrm{GDP}$ & $0.568^{*}$ & 0.116 & 4.88 & $0.463^{*}$ & 0.116 & 3.99 & & \\
\hline$\Delta$ Finance & -0.000 & 0.003 & -0.02 & -0.000 & 0.003 & -0.15 & & \\
\hline$\Delta$ Inflation & -0.001 & 0.001 & -0.29 & 0.000 & 0.000 & 0.13 & & \\
\hline
\end{tabular}

Note. PMG model constrains the long-run coefficient vector to be equal across countries while allowing for group-specific short-run and adjustment coefficients. MG model allows all parameters to vary across countries and fits parameters as averages of the $\mathrm{N}$ individual group regressions. The Hausman test is a test of the restriction that all countries have the same long-run coefficients. The null of homogenous long-run coefficient is accepted at $5 \%(10 \%)$ when the $p$-values are bigger than $0.05(0.01)$. * indicates significance at $5 \%$. 


\section{Conclusion and Policy Implications}

This study applied the pooled mean group estimation method to analyse the effect of budget deficit on private consumption in seven member countries of the West African Economic and Monetary Union (WAEMU) over the period 1970 to 2013. The estimated results show that budget deficit caused by public spending and per capita GDP have long run positive effects on household consumption whereas inflation rate is detrimental to private consumption. This suggests that private consumption cannot be held responsible for any crowding-out effects that budget deficit might have on aggregate demand and economic growth in WAEMU countries. However, budget deficit has no significant effect on private consumption in the short run, suggesting that fiscal policy is not so powerful in stimulating private demand in short run.

Our results have several policy implications and suggestions for future research. First, restricting the size of budget deficits is costly for the development of WAEMU countries. Policy makers should use public spending to promote economic growth and invest in pro-poor sectors. Second, the central bank and governments should continue enforcing sound policies to control inflation rates. A stable macroeconomic environment is a fundamental prerequisite for healthy financial sector development. Third, as economic growth is not a sufficient condition for achieving poverty reduction, the study suggests that to accelerate poverty reduction economic growth needs to be more inclusive to reach all segments of population including the poor. To this end, governments should adopt measures improving access to credit to the poor that will create more employment opportunities. Four, as the control of budget deficits is a prerequisite for sustainable growth and real convergence within a monetary union, efforts should be made to rationalize public expenditure and improve tax revenues mobilization. An interesting topic for further research is to determine the threshold level of budget deficit relatively to private consumption.

\section{References}

Afzal, M. (2012). Ricardian equivalence hypothesis: Evidence from Pakistan. Journal of Business Management and Economics, 3(6), 258-265.

Barro, R. (1989). The Ricardian approach to budget deficits. Journal of Economic Perspectives, 3(2), 37-54. http://dx.doi.org/10.1257/jep.3.2.37

Berben, R., \& Brosens, T. (2007). The impact of government debt on private consumption in OECD Countries. Economics Letters, 94(2), 220-225. http://dx.doi.org/10.1016/j.econlet.2006.06.033

Bernheim, B. D. (1989). A neoclassical perspective on budget deficits. Journal of Economic Perspectives, 3(2), 55-72. http://dx.doi.org/10.1257/jep.3.2.55.

Besley, T., \& Burgess, R. (2003). Halving global poverty. Journal of Economic Perspectives, 17(3), 3-22. http://dx.doi.org/10.1257/089533003769204335

Cardia. E. (1997). Replicating ricardian equivalence test with simulated series. The American Economic Review, 87(1), 65-79.

Drakos, K. (2001). Testing the ricardian equivalence theorem: time series evidence from Greece. Journal of Economic Development, 26(1), 1-12.

Ghatak, A., \& Ghatak, S. (1996). Budgetary deficits and ricardian equivalence: The case of India, 1950-1986. Journal of Public Economics, 60(2), 267-282. http://dx.doi.org/10.1016/0047-2727(95)01551-5

Giorgioni, G., \& Holden, K. (2003). Does the ricardian equivalence proposition hold in less developed countries? $\begin{array}{lllll}\text { International Review of Applied } & \text { Economics, } & \text { 17(2), } & \text { 209-221. }\end{array}$ http://dx.doi.org/10.1080/0269217032000064062

Granger, C. W. J., Huang, B. N., \& Yang, C. W. (2000). A bivariate causality between stock prices and exchange rates: Evidence from recent Asianflu. The Quarterly Review of Economics and Finance, 40(3), 337-354. http://dx.doi.org/10.1016/S1062-97695(00)00042-9

Gupta, K. L. (1992). Ricardian equivalence and crowding out in Asia. Applied Economics, 24(1), 19-25. http://dx.doi.org/10.1080/00036849200000099

Haque, N. U. (1988). Fiscal policy and private sector saving behaviour in developing economies. IMF Staff Papers, 35, 316-335.

Haque, N. U., \& Montiel, P. (1989). Consumption in developing countries: Tests for liquidity constraints and finite horizons. The Review of Economics and Statistics, 71(3), 408-415.

Haque, N., \& Montiel. (1991). Macroeconomics of public sector deficit: the case of Pakistan. World Bank Policy 
Research Working Paper, 673.

Haug, A. A. (2002). Temporal aggregation and the power of cointegration tests: A Monte Carlo study. Oxford Bulletin of Economics and Statistics, 64(4), 399-412. http://dx.doi.org/10.1111/1468-0084.00025.

Ho, T. W. (2001). The government spending and private consumption: A panel cointegration analysis. International Review of Economics and Finance, 10(1), 95-108. http://dx.doi.org/10.1016/S1059-0560(00)00073-3

Karras, G. (1994). Government spending and private consumption: Some international evidence. Journal of Money, Credit and Banking, 26, 9-22.

Keynes, J. M. (1936). The general theory of interest, employment and money. London: McMillan.

Khalid, A. M. (1996). Ricardian equivalence: Empirical evidence from developing economies. Journal of Development Economics, 51(2), 413-432. http://dx.doi.org/10.1016/S0304-3878(96)00422-1

Khan, K., Fei, C., Kamal, M. A., \& Ashraf, B. N. (2015). Impact of government spending on private consumption using ARDL approach. Asian Economic and Financial Review, 5(2), 239-248.

Kormendi, R. C. (1983). Government debt, government spending, and private sector behaviour. American Economic Review, 73(5), 994-1010.

Modigliani, F., \& Sterling, A. (1986). Government debt, government spending and private sector behavior: Comment. American Economic Review, 76(5), 1168-1179.

Nieh, C. C., \& Ho, T. (2006). Does the expansionary government spending crowd out the private consumption? cointegration analysis in panel data. The Quarterly Review of Economics and Finance, 46(1), 133-148. http://dx.doi.org/10.1016/j.qref.2004.11.004

Pesaran, H., Shin, Y., \& Smith, R. J. (2001). Bounds testing approaches to the analysis of level relationships. Journal of Applied Econometrics, 16(3), 289-326. http://dx.doi.org/10.1002/jae.616

Pesaran, M. H., \& Smith, R. P. (1995). Estimating long-run relationship from dynamic heterogenous panels. Journal of Econometrics, 68(1), 79-113. http://dx.doi.org/10.1016/0304-4076(94)01644-F

Pesaran, M. H., Shin, Y., \& Smith, R. P. (1999). Pooled mean group estimation of dynamic heterogeneous panels. Journal of the American Statistical Association, 94(446), 621-634. http://dx.doi.org/10.2307/2670182

Phillips, P. C. B., \& Perron, P. (1988). Testing for a unit root in a time series regression. Biometrika, 75(2), 335-346. http://dx.doi.org/10.1093/biomet/75.2.335

Rock, L. L., Craigwell, R. C., \& Sealy, R. C. (1989). Public deficits and private consumption: Empirical evidence from small open economies. Applied Economics, 21(5), 697-710. http://dx.doi.org/10.1080/758524900

Schclarek, C. (2007). Fiscal policy and private consumption in industrial and developing countries. Journal of Macroeconomics, 29(4), 912-939. http://dx.doi.org/10.1016/j.jmacro.2006.03.002

Shaw, K. G. (1987). Macroeconomic implications of fiscal deficits. Scottish Journal of Political Economy, 34(2), 192-199. http://dx.doi.org/10.1111/j.1467-9485.1987.tb00278.x

Tagkalakis, A. (2008). The effects of fiscal policy on consumption in recessions and expansions. Journal of Public Economics, 92(5-6), 1486-1508. http://dx.doi.org/10.1016/j.jpubeco.2007.11.007

Wheeler, M. (1999). The Macroeconomic impacts of government debt: An empirical analysis of the 1980s and the 1990s. Atlantic Economic Journal, 27(3), 273-285. http://dx.doi.org/10.1007/BF02299578

World Bank. (1990). World Development Report 1990: Poverty. New York: Oxford Univerty Press.

\section{Copyrights}

Copyright for this article is retained by the author(s), with first publication rights granted to the journal.

This is an open-access article distributed under the terms and conditions of the Creative Commons Attribution license (http://creativecommons.org/licenses/by/3.0/). 